Jurnal Ilmu-Ilmu Peternakan 26 (2): 42 - 48

ISSN : 0852-3681

E-ISSN : 2443-0765

CFakultas Peternakan UB, http://jiip.ub.ac.id/

\title{
Korelasi antara bobot badan induk dengan litter size, bobot lahir dan mortalitas anak kelinci New Zealand White
}

\author{
Sismala Widitania, Yon Soepri Ondho, dan C. M. Sri Lestari \\ Fakultas Peternakan dan Pertanian Universitas Diponegoro Semarang \\ sismala.widitania@gmail.com
}

\begin{abstract}
This study aims to determine the relationship between body weight of does with litter size, birth weight and mortality in New Zealand White (NZW) rabbits. The research was conducted at the Central Breeding and Raising Non Ruminant Livestock unit Balekambang, Surakarta, Central Java. The material used in this study was 35 does that had sexual maturity and have given birth at least once aged maximum 3 years old. In addition, the study also used 7 bucks aged approximately 2 years. Data were analysed using simple linear regression analysis. The study found that the weight of the does had a very weak correlation value to litter size, birth weight and mortality of young rabbits.
\end{abstract}

Keywords: Rabbits, New Zealand White, body weight, litter size

\section{PENDAHULUAN}

Tingkat konsumsi daging masyarakat merupakan salah satu aspek yang menentukan derajat kesehatan suatu bangsa. Menurut OECD (2016), konsumsi daging masyarakat Indonesia tahun 2015 adalah 11,2 kg per kapita yang jauh di bawah angka konsumsi daging rata-rata dunia yang mencapai 34,1 kg per kapita. Oleh karena itu, diperlukan upaya meningkatkan produksi daging di Indonesia agar dapat memenuhi kebutuhan daging.

Kelinci New Zealand White sebagai produsen daging komersial memiliki beberapa keunggulan yaitu tingkat pertumbuhan yang cepat, kualitas karkas, kesuburan, dan kemampuan pengasuhan yang baik (Lebas et al., 1986). Daging kelinci mengandung protein 20,8\%, lemak $10,2 \%$ dan energi $7,3 \mathrm{MJ} / \mathrm{Kg}$, kandungan asam lemak linoleat tertinggi diantara ternak lainnya (22,5\%), kandungan kolesterol relatif rendah $0,1 \%$ dan sedikit garam (Hutasuhut, 2005).

Budidaya kelinci di Indonesia relatif lebih sedikit dibandingkan dengan budidaya ternak lain seperti ayam, sapi, kambing dan domba. Pemeliharaan kelinci relatif mudah dan pakan untuk kelinci juga mudah diperoleh. Salah satu aspek yang mempengaruhi keberhasilan usaha peternakan kelinci adalah bibit ternak. Berbagai acuan telah digunakan dalam seleksi bibit kelinci unggul diantaranya bobot lahir, litter size dan mortalitas.

Litter size sangat dipengaruhi oleh jumlah ovum (sel telur) yang diovulasikan oleh induk. Persentase ovulasi kelinci berkorelasi dengan bobot badan (Weisbroth, 1974). Jumlah sel telur yang diovulasikan dan yang dibuahi oleh sperma serta jumlah sel 
telur yang dibuahi yang mengalami perkembangan intrauterin merupakan faktor yang menentukan litter size (McNitt et al., 2013).

Kelinci memiliki uterus dupleks (Bensley, 1948) dan terdapat kecenderungan transplantasi ovum bahwa pada kelinci yang lebih besar akan menerima lebih banyak daripada yang agak kecil (Venge, 1950). Ruang yang tersedia pada uterus mempengaruhi perkembangan plasenta induk dan pada tingkat yang lebih rendah juga mempengaruhi perkembangan fetus dan plasenta dari fetus. Panjang uterus dan ruang yang tersedia didalamnya memiliki efek agak kecil terhadap pertumbuhan fetus dan berat fetus (Bolet et al., 2007).

Litter size yang lahir hidup adalah cerminan dari kesuburan kelinci betina dan kemampuannya dalam mengasuh anak yang dilahirkan (McNitt et al., 2013). Induk yang diinseminasi pada umur 14,5 minggu menghasilkan persentase kelahiran mati yang lebih tinggi pada induk yang lebih berat (bobot badan> $4 \mathrm{~kg}$ ) dibandingkan dengan induk yang kecil (bobot badan $<3,5 \mathrm{~kg}$ ) yaitu masing-masing sebesar 13,4\% dan 4,6\% (Rommers et al. 2002). Jumlah kelahiran mati meningkat pada induk kelinci dengan konsumsi pakan rendah saat bunting (Rommers et al. 2006).

Penelitian ini bertujuan untuk mengetahui hubungan antara bobot badan induk dengan litter size, bobot lahir dan mortalitas anak kelinci NZW. Diduga semakin tinggi bobot induk maka semakin tinggi litter size, semakin tinggi bobot lahir anak dan semakin kecil mortalitas anak kelinci.

\section{MATERI DAN METODE}

Penelitian ini dilaksanakan pada tanggal 2 Maret sampai 1 Mei 2016.
Materi yang digunakan dalam penelitian adalah kelinci milik Balai Pembibitan dan Budidaya Ternak Non Ruminansia (BPBTNR) Satuan Kerja Balekambang, Surakarta, Jawa Tengah. Induk kelinci yang digunakan sebanyak 35 ekor yang sudah dewasa kelamin dan minimal pernah melahirkan 1 kali dengan umur maksimal 3 tahun. Selain itu digunakan pula 7 ekor pejantan kelinci yang berumur kurang lebih 2 tahun.

Penimbangan induk dilakukan sebelum kelinci dikawinkan. Kelinci dikawinkan secara alami dengan memindahkan kelinci betina pada kandang jantan. Setelah kawin, kelinci betina dikembalikan ke kandang pengamatan. Pemeriksaan kebuntingan dilakukan pada 2 minggu setelah kawin. Induk yang bunting dirawat dan ditunggu sampai melahirkan, sedangkan induk yang tidak bunting ditimbang bobotnya kemudian dikawinkan kembali. Kurang lebih satu minggu sebelum melahirkan, kandang kelinci diberi kotak yang digunakan sebagai sarang. Induk kelinci akan merontokkan bulu untuk penghangat pada sarang dan kemudian melahirkan.

Parameter penelitian antara lain bobot induk sebelum dikawinkan, litter size, bobot lahir anak dan mortalitas anak kelinci yang baru lahir.

Data dianalisis dengan regresi linear sederhana untuk mengetahui korelasi antara bobot badan induk dengan litter size, bobot badan induk dengan bobot lahir anak dan bobot badan induk dengan mortalitas anak.

\section{HASIL DAN PEMBAHASAN}

Hasil penelitian rata-rata bobot induk, litter size, bobot lahir dan mortalitas kelinci New Zealand White (NZW) ditampilkan pada Tabel 1. 
Tabel 1. Rata-rata bobot badan induk, litter size, bobot lahir, dan mortalitas kelinci New Zealand White

\begin{tabular}{lc}
\hline & Rata-rata \pm SD \\
\hline Bobot induk (g) & $2.168,51 \pm 428,85$ \\
Litter size (ekor) & $4,31 \pm 1,69$ \\
Bobot lahir (g) & $50,78 \pm 12,85$ \\
Mortalitas (ekor) & $0,09 \pm 0,37$ \\
\hline
\end{tabular}

\section{Korelasi antara bobot induk dengan litter size}

Berdasarkan data pada Tabel 1 tersebut, rata-rata bobot induk kelinci NZW hasil penelitian adalah 2.168,51 \pm 428,85. Bobot tersebut lebih rendah dibandingkan dengan bobot induk kelinci NZW normal. Menurut Raharjo dan Brahmantiyo (2006), bobot anak NZW umur 58 hari sekitar 1,8 kg sedangkan bobot dewasa rata-rata 3,6 kg bahkan dapat mencapai 4,5-5 kg per ekor. Sama halnya dengan bobot induk, rata-rata litter size hasil penelitian juga menunjukkan hasil di bawah rata-rata litter size kelinci NZW normal. Menurut Lebas et al. (1986), litter size rata-rata kelinci New Zealand White antara 7-9. Korelasi antara bobot induk dengan litter size pada kelinci New Zealand White ditampilkan pada Tabel 2.

Tabel 2. Hasil korelasi dan regresi sederhana antara bobot induk dengan litter size kelinci New Zealand White

\begin{tabular}{lc}
\hline & Bobot induk - Litter size \\
\hline Koefisien korelasi $(\mathrm{r})$ & $-0,005$ \\
Koefisien determinasi $\left(\mathrm{R}^{2}\right)$ & $0,0025 \%$ \\
Persamaan regresi & $\mathrm{Y}=5512,34-2,54 \mathrm{X}$ \\
\hline
\end{tabular}

Hasil korelasi sebesar -0,005 menunjukkan bahwa hubungan antara bobot badan dengan litter size sangat lemah. Ini berarti bobot badan induk hampir tidak ada hubungannya dengan litter size. Menurut Weisbroth (1974), bobot badan kelinci berkorelasi dengan persentase ovulasi dimana jumlah sel telur yang diovulasikan akan mempengaruhi litter size. Tarsono dkk. (2009) menyatakan bahwa semakin banyak jumlah sel telur yang diovulasikan, jumlah sel telur yang dibuahi akan semakin banyak sehingga jumlah anak sekelahiran (litter size) juga meningkat. Apabila bobot badan induk mempengaruhi jumlah sel telur yang diovulasikan dan jumlah telur yang diovulasikan mempengaruhi litter size, maka bobot induk seharusnya akan mempengaruhi litter size kelinci.
Rendahnya nilai korelasi dimungkinkan terjadi karena litter size pada kelinci bukan hanya dipengaruhi oleh banyaknya sel telur yang diovulasikan saja, melainkan terdapat faktor-faktor lain yang mempengaruhi, antara lain induk kelinci dan lingkungan. Induk kelinci dapat mengovulasikan beberapa buah sel telur namun belum tentu semua sel telur yang telah diovulasikan tersebut akan mengalami pembuahan dan perkembangan. Menurut Moreki (2007), litter size yang lebih kecil dapat terjadi karena kelinci jantan yang terlalu sering digunakan untuk mengawini betina. Pejantan yang sering digunakan untuk mengawini kelinci betina kemungkinan dapat mengakibatkan berkurangnya jumlah sel telur yang terbuahi. 
Selain itu, tidak semua sel telur yang telah dibuahi dapat berkembang dengan baik didalam uterus. Kematian fetus dan jumlah sel telur yang sudah dibuahi dan hilang selama kebuntingan juga mempengaruhi jumlah anak sekelahiran (Tarsono dkk., 2009). Kebanyakan kematian embrio terjadi pada 15 hari sebelum kelahiran yang dapat disebabkan karena viabilitas embrio dan faktor eksternal yaitu musim serta kondisi fisiologis kelinci betina terutama umur (Lebas et al., 1986). Selain umur, kesehatan induk juga berpengaruh terhadap litter size. Menurut De Blas dan Wiseman (2010), gejala defisiensi seperti anemia, kehilangan nafsu makan, kulit kasar, dan diare dapat mengurangi ukuran litter size. Hubungan antara bobot induk dengan litter size kelinci New Zealand White diperjelas melalui garis regresi yang terdapat pada Gambar 1.

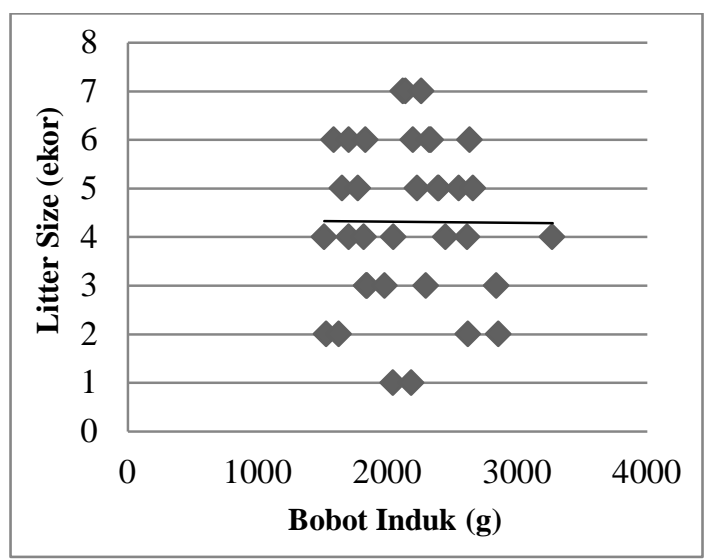

Gambar 1. Garis regresi antara bobot badan induk dengan litter size pada kelinci New Zealand White

\section{Korelasi antara bobot induk dengan bobot lahir anak}

Bobot lahir rata-rata anak kelinci hasil penelitian adalah 50,78 gram (lihat Tabel 1). Hasil tersebut lebih rendah dari bobot lahir kelinci New Zealand
White yang dikemukakan oleh McNitt et al. (2013) yakni sekitar 60 gram. Korelasi antara bobot induk dengan bobot lahir anak kelinci New Zealand White dapat dilihat pada Tabel 3.

Tabel 3. Hasil korelasi dan regresi sederhana antara bobot induk dengan bobot lahir anak kelinci New Zealand White

\begin{tabular}{|c|c|}
\hline & Bobot induk - Bobot lahir anak \\
\hline Koefisien korelasi (r) & 0,14 \\
\hline Koefisien determinasi $\left(\mathrm{R}^{2}\right)$ & $1,96 \%$ \\
\hline Persamaan regresi & $Y=39,93+0,005 X$ \\
\hline $\begin{array}{l}\text { Hasil korelasi yang rendah pada } \\
\text { Tabel } 3 \text { dimungkinkan karena tidak } \\
\text { dilakukan pengelompokan terhadap } \\
\text { litter size. Korelasi bobot anak dengan } \\
\text { bobot induk dari kelinci Large apabila } \\
\text { dihitung secara total sebesar } 0,1566 \text {. }\end{array}$ & $\begin{array}{l}\text { Namun apabila dilakukan } \\
\text { pengelompokan berdasarkan litter size } \\
\text { korelasinya meningkat menjadi } 0,4868 \text {, } \\
\text { sedangkan untuk kelinci Polish korelasi } \\
\text { bobot induk dengan bobot lahir anak } \\
\text { secara total adalah } 0,0247 \text {, tetapi ketika }\end{array}$ \\
\hline
\end{tabular}


sudah dikelompokkan menjadi 0,1079. Hal ini menunjukkan bahwa dalam perhitungan korelasi dengan pengelompokan litter size yang sama, terdapat hubungan antara bobot induk dengan bobot anak.

Menurut Venge (1950), faktor mempengaruhi bobot lahir kelinci adalah lama periode kebuntingan, pengaruh musim, umur induk dan berapa kali induk beranak, ukuran tubuh induk, jenis kelamin anak, serta litter size. Ukuran induk dimungkinkan akan mempengaruhi ukuran uterus. Panjang uterus dan ruang yang tersedia didalamnya sedikit berpengaruh terhadap pertumbuhan fetus dan berat fetus (Bolet et al., 2007). Hubungan antara bobot induk dengan bobot lahir anak kelinci New Zealand White diperjelas melalui garis regresi pada Gambar 2.

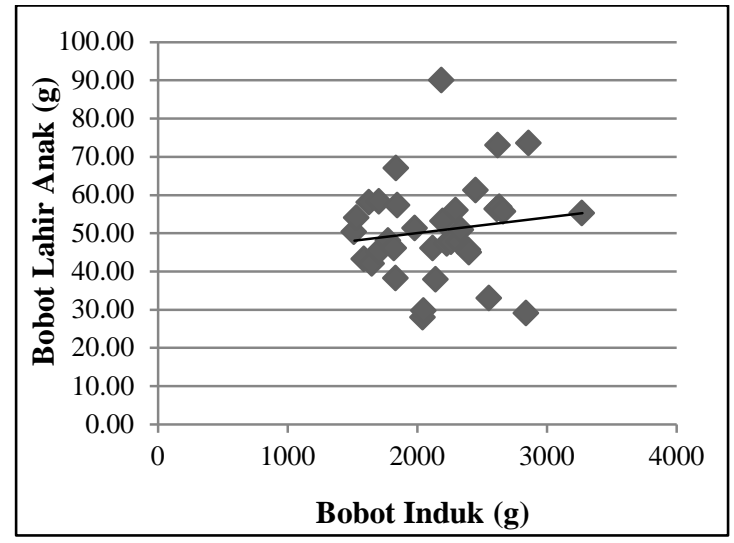

Gambar 2. Garis regresi antara bobot badan induk dengan bobot lahir anak pada kelinci New Zealand White

\section{Korelasi antara bobot induk dengan mortalitas anak}

Hasil pengukuran korelasi antara bobot induk dengan mortalitas anak pada kelinci New Zealand White dapat dilihat pada Tabel 4. Rata-rata angka mortalitas anak kelinci saat dilahirkan sebesar 0,09 atau tergolong rendah. Sebagian besar anak kelinci hasil penelitian dapat bertahan hidup pada saat dilahirkan. Hal ini dimungkinkan karena seluruh induk kelinci pada penelitian memiliki bobot yang rendah.
Menurut Rommers et al. (2002), induk yang diinseminasi pada umur 14,5 minggu menghasilkan persentase kelahiran mati yang lebih tinggi pada induk yang lebih berat (bobot badan $>4$ $\mathrm{kg}$ ) dibandingkan dengan induk yang kecil (bobot badan $<3,5 \mathrm{~kg}$ ) yaitu masing-masing sebesar $13,4 \%$ dan 4,6\%. Litter size yang lahir hidup adalah cerminan dari kesuburan kelinci betina dan kemampuannya dalam mengasuh anak yang dilahirkan (McNitt et al., 2013).

Tabel 4. Hasil korelasi dan regresi sederhana antara bobot induk dengan mortalitas anak kelinci New Zealand White

\begin{tabular}{lc}
\hline & Bobot induk - Mortalitas anak \\
\hline Koefisien korelasi $(\mathrm{r})$ & 0,12 \\
Koefisien determinasi $\left(\mathrm{R}^{2}\right)$ & $1,4 \%$ \\
Persamaan regresi & $\mathrm{Y}=-2298,54+1,06 \mathrm{X}$ \\
\hline
\end{tabular}


Hasil penelitian mencatat bahwa kematian anak kelinci yang baru lahir berasal dari induk kelinci yang berumur $\leq 1$ tahun. Umur induk merupakan salah satu faktor yang dapat mempengaruhi kelahiran mati. Menurut Lebas et al. (1986), faktor eksternal yang juga berperan pada kematian embrio kelinci adalah musim dan kondisi fisiologis kelinci betina terutama umur.

Poigner et al., (2010) menyatakan bahwa litter size dan bobot lahir juga dapat mempengaruhi mortalitas dimana pada litter yang besar biasanya bobot lahir akan kecil dan apabila tidak dilakukan homogenisasi biasanya dapat meningkatkan angka mortalitas. Hubungan antara bobot induk dengan mortalitas anak kelinci New Zealand White diperjelas melalui garis regresi yang disajikan pada Gambar 3.

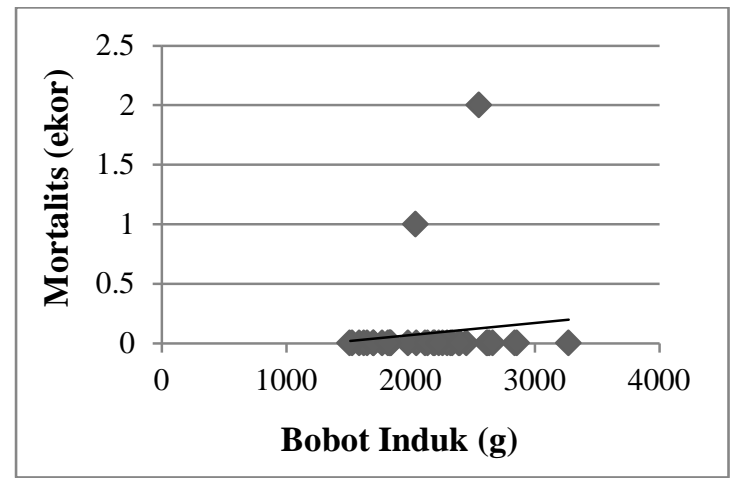

Gambar 3. Garis regresi antara bobot badan induk dengan mortalitas anak kelinci New Zealand White

\section{KESIMPULAN}

Bobot induk kelinci New Zealand White mempunyai nilai korelasi yang sangat lemah terhadap litter size, bobot lahir anak, dan mortalitas anak kelinci. Hal tersebut menunjukkan bahwa bobot induk tidak terlalu menentukan besarnya litter size, bobot lahir anak dan mortalitas anak kelinci New Zealand White.

\section{DAFTAR PUSTAKA}

Bensley, B. A. 1948. Practical anatomy of the rabbit: $8^{\text {th }} \mathrm{Ed}$. University of Toronto Press, Philadelphia.

Bolet, G., H. Garreau, T. Joly, M. Theau-Clement, J. Falieres, J. Hurtaud, dan L. Bodin. 2007. Genetic homogenisation of birth weight in rabbits: Indirect selection response for uterine horn characteristics. Jour. Live. Sci. 111 : 28-32

De Blas, C. dan J. Wiseman. 2010. Nutrition of the rabbit. CABI, Wallingford.

Hutasuhut, M. 2005. Strategi pengembangan usaha ternak kelinci mendukung agribisnis peternakan: Dukungan kebijakan. Prosiding Lokakarya Nasional Potensi dan Peluang Pengembangan Usaha Kelinci, Bandung, 30 September 2005. Pusat Penelitian dan Pengembangan Peternakan, Bandung : 3-5.

Lebas, F., P. Coudert, R. Rouvier \& H. D. Rochambeau. 1986. The rabbit husbandry, health and 
production. Food and Agriculture Organization of The United Nation, Rome.

McNitt, J. I., S. D. Lukefahr, P. R. Cheeke, dan N. M. Patton. 2013. Rabbit production: $9^{\text {th }}$ Ed. CABI, Wallingford.

Moreki, J. C. 2007. Commercial rabbit production. Agrinews Magazine 38 (10) : 2-12.

OECD. 2016. Meat consumption (indicator). doi: 10.1787/fa290fd0-en (Diakses pada 07 August 2016)

Poigner, J., Zs, S., Levai, A., Radnai, I., \& Biro-Nemeth, E. (2010). Effect of birth weight and litter size on growth and mortality in rabbits. World Rabbit Science 8 (1): 17-22.

Raharjo, Y. C. dan B. Brahmantiyo. 2006. Plasma nutfah kelinci sebagai sumber pangan hewani dan produk lain bermutu tinggi. Prosiding Lokakarya Nasional Pengelolaan dan Perlindungan Sumber Daya Genetik di Indonesia, Bogor, 20 Desember 2006. Pusat Penelitian dan Pengembangan Peternakan, Bogor : 257-265.
Rommers, J. M., R. Meijerhof, J. P. T. M. Noordhuizen, B. Kemp, 2002. Relationships between body weight at first mating and subsequent body development, feed intake, and reproductive performance of rabbit does. Jour. Anim. Sci. 80: 2036-2042.

Rommers, J. M., L. Maertens dan B. Kemp. 2006. New perspectives in rearing systems for rabbit does. Dalam: Maertens, L. dan P. Coudert. (eds) Recent advances in rabbit sciences. COST and ILVO, Melle. hlm. 39-52.

Tarsono, Najamudin, Mustaring, Y. Duma dan Supriono. 2009. Performa litter kelinci induk lokal yang diberi pakan hijauan ubi jalar disuplementasi sejumlah konsentrat berbeda. J. Agroland 16 (1) : 78-84.

Venge, O. 1950. Sudies of maternal influence on the birth weight in rabbits. Jour. Act. Zool. 31 (1): 1-148.

Weisbroth, S. H. 1974. The biology of the laboratory rabbit. Academic Press, London. 